\title{
Textual Analysis of College Anthem and Its Implication for Sustainable Development in Nigeria
}

\author{
Justina Enoh Okafor \\ http://dx.doi./org/10.4314/ujah.v21i3.14
}

\begin{abstract}
The paper is based on the content analysis of the College Anthem. The College anthem is a composition written by Elsie E. Nwoko reflecting core value of the College of Education, Agbor. The text of the college anthem is very significant in that the text is an intricate musicality woven into the fabric of the existence of the College of Education and the tenet of institution. Without the existence of the College of Education Agbor, there would be no composition known as the College Anthem. The paper followed the descriptive and empirical approach in realizing set objective by juxtaposing the College Anthem vis-a-vis the College of Education, Agbor in relation to sustainable development. The paper concludes that since music can be used as an advertising agent, and the College exists for capacity/capital development of Nigeria citizens, the Music Department as a unit of the College of Education, Agbor should be assisted and encouraged in all ramification to run the music programme effectively in order to contribute to the sustainable development of Nigeria via each empowered graduates from the music programme.
\end{abstract}

Keywords: Sustainable development, College, Anthem, Textual, analysis

\section{Introduction}

The term analysis has been dissected diversely by different authors.

Merriam-Webster define analysis as 'a detailed examination of anything complex in order to understand its nature or to determine its 
essential features'. Analysis is the process of breaking a complex topic or substance into smaller parts in order to gain a better understanding of it.

According to Business Dictionary analysis is 'a systematic examination and evaluation of data or information, by breaking it into its component parts to uncover their interrelationships or an examination of data and facts to uncover and understand cause-effect relationships, thus providing basis for problem solving and decision making'. According to Bent and Pople (2001) analysis may be said to include the interpretation of structures in music, together with their resolution into relatively simpler constituent elements and the investigation of the relevant functions of those elements (p. 526). Wikipedia define analysis as 'an attempt to answer the question: How does this music work? The method employed to answer this question. It also note that, what is meant by the question differ from analyst to analyst, and according to the purpose of the analysis.

According to a Webster online dictionary, analysis means the following: separation of a whole into its component parts; the identification of separation of ingredients of a substance; a statement of the constituents of a mixture; proof of a mathematical proposition by assuming the result and deducing a valid statement by a series of reversible steps; an examination of a complex, its elements, and their relations; a statement of such an analysis; a method in philosophy of resolving complex expressions into simpler or more basic ones; clarification of an expression by an elucidation of its use in discourse and the use of function words instead of inflectional forms as a characteristic device of a language.

In summary, analysis is a breakdown of whole components into smaller component; it is an x-ray of the entirety of a work with a view to highlighting its strength and weaknesses and providing a workable theory for further improvement if any. 
Textual analysis on the other hand, is a method of data analysis that closely examines either the content and meaning of texts or their structure and discourse. In McKee's (2001) opinion, textual analysis point to the importance context, genre and modality. When we perform textual analysis on a text, we make an educated guess at some of the most likely interpretations of that might be made of that text. He further stated that there is no such thing as a single, 'correct' interpretation of any text. There are large numbers of possible interpretations, some of which will be more likely than others in particular circumstances. This assumption is inherent in the very word 'text'. As soon as we describe a programme, magazine or book as a 'text' we are implying a certain approach to it, and a certain way of making sense of it; including the fact that we do not think it has a single correct interpretation. Summarily, textual analysis is the breakdown or disserting of the text of a book, poem, and or music composition line by line, paragraph by paragraph, sentence by sentence and phrase by phrase for the purpose of achieving a set objective portended by the analyst.

Analyzing the textual content of the College Anthem is very significant in that the College of Education, Agbor as an education section is an avenue for creating sustainable development in Nigeria which has been a song sung by many stakeholders of economy, educationist and Politicians for decades. The song is still being sung in this $21^{\text {st }}$ century. How can sustainable development be realized in Nigeria? Sustainable development can be achieved and realized via institutions, education being one. How is the College Anthem composed by Elsie E. Nwoko related to sustainable development? The answer can be fathomed from the text.

\section{The Concept of Sustainable Development}

According to Brundtland Report of 1987 Sustainable development is the development that meets the needs of the present without 
compromising the ability of future generations to meet their own needs. This definition acknowledges that while development may be necessary to meet human needs and improve the quality of life, it must happen without depleting the capacity of the natural environment to meet present and future needs. Sustainable development abbreviated (EDU) is defined as Education for Sustainable Development that allows every human being to acquire the knowledge, skills, attitudes and values necessary to shape sustainable future (UNESCO, 2014). Wikipedia, state that sustainable development was a United Nations programme that is defined as education that encourages changes in knowledge, skills, values and attitudes to enable a more sustainable and just society for all.

The concept of Education for Sustainable Development was born from the need for education to address the growing and changing environmental challenges facing the planet. In order to do this, education must change to provide the knowledge, skills, values and attitudes that empower learners to contribute to sustainable development. Education for sustainable development aims to produce learning outcomes that include core competencies such as critical and systematic thinking, collaborative decision-making, and taking responsibility for the present and future generations. It promotes social equity and encourages economic sustainability.

Education is a key to achieving sustainable development the world over and in Nigeria in particular. Eya (2000) in Aninwene (2006:70) see education as the sum total of process by means of which a community or social group (ethnic groups) whether small or large transmits its acquired power and aims with a view to securing its continuous existence or growth. Ekong (2008) observe that the greatest challenge to any society is its ability to produce an environment and opportunities conducive for its citizenry to be selfreliant and render service to it for its development and self- 
sufficiency. Therefore, every society, simple to complex engages in enterprises that will augur well for the well-being of its citizenry. In response to the challenge of building opportunities and producing conducive and enabling environment for its citizenry in Delta State, Agbor to be particular, the College of Education Agbor was birthed. This is found in the texts of the College Anthem. College of Education, Agbor, became a rallying field of endeavour for human development, ensuring that the citizen of Nigeria, Delta State and Ika land particularly are sold the opportunity to become self-sustainable. Human capacity building and sustainable development feature in the College Anthem:

'For the Good of Man our motto is'

College of Education, Agbor,

Loyalty, hard work is our pledge

We shall fight to bring you fame

The College Anthem cannot be discussed without having an overview on the historical perspective. See below:

\section{Brief Perspective on College of Education, Agbor}

The College of Education, Agbor, was established in October, 1979 by the then Bendel State Government of Late Prof. Ambrose F. Ali. In November 1980 the College took off at the site of the former Local Authority Modern School (directly opposite the Central Hospital on the new Uromi/Abraka Road) which was then being used by the Institution of Continuing Education at Alihame Agbor. The pioneer Provost, Dr. E. A. Tetsola used his connections to get the Ministry of Education to second some of its staff to the college. These pioneer staff formed the bedrock of a dedicated and dynamic crop of staff of the college.

On August $18^{\text {th }} 1981$ late Prof. Ambrose F. Ali., then Governor of Bendel State performed the official opening of the college. In April 1982, the Federal Government of Nigeria, through 
its agency on Education, the National Council on Education formally recognized College of Education Agbor as an NCE awarding institution, thus making its certificate acceptable in all parts of the federation and beyond. In June 1988, the college was formally approved as a scheduled service by the Federal Government.

As the need for a permanent site became very urgent, the college found its immediate hosts, the Alihame Community worthy partners in progress. The community willingly donated a large parcel of land including Dr. G. O. Orewa who also unanimously gave his large expanse of land which was within the larger area transferred to the College. The College has various schools of education namely; Arts and social sciences, business education, vocational and technical education, school of sciences and school of languages and School of Education. Today most of these schools have moved to the permanent site due to large population of students.

The Pioneer Provost, Dr. E. A. Tetsola was a motivator par excellence. He had time to personally interact with the fine crop of highly motivated young lecturers and other members of staff he had put together. By the time he left the college in January 1985 for his doctoral programme at the University of Benin, an amicable academic culture was already in place. He had improved and expanded facilities on the temporary site (known as old site) and the parcel of land for the permanent site was in place.

The following are Schools under the College of Education, Agbor

1. School of Arts and Social Sciences

2. School of Vocational Studies and Tech

3. School of Sciences

4. School of Education

5. School of Languages

Each of the above Schools has the following departments 


\section{School of Arts and Social Sciences}

Music Department

Theatre Arts Department

Social Studies Department

Political Science Department

History Department

Economics Department

Christian Religious Studies Department

\section{School of Vocational Studies and Tech}

Agricultural Education Department

Home Economics Department

Accounting Department

Secretariat Studies Department

\section{School of Sciences}

Integrated Science Department

Biology Department

Chemistry Department

Computer Science Department

Mathematics Department

\section{School of Education}

Educational Foundational/Administration Department

Primary Education Studies Department

Early Childhood Care Education Department

Curriculum Department

Educational Psychology Department

\section{School of Languages}

English Department

French Department 
Nigerian Languages

The institution also comprises the General Studies in Education Department and the Library Science Department. Recently, the College commenced the Center for Entrepreneurial Education Studies and Skills Acquisition. These departments run by the College of Education, Agbor are geared towards the production of human capacity development also geared towards producing manpower to sustain the economy of Nigeria through meaningful decision-making, skill production and contribution.

\section{Textual Analysis of the College Anthem}

Music is a uniquely human form of communication with well developed rules of construction much like in grammar. Some language experts would say that you can listen to someone and still know whether the speaker is excited or tired, angry or delighted. You would be making interpretations based upon the speech patterns: loud or soft, high-pitched or low-pitched, rapid and bitten off, slow or smooth. Corresponding to these elements of speech are musical variables such as dynamics (force and volume), register (range of music or voice), mode (arrangement of a set of tones) and articulation (such as staccato or legato). Although there is no general agreement as to exactly what music communicates or how it communicates, music possesses great powers of communication.

Verbal music communication in form of song texts, are more explicitly and easily comprehended. Therefore, textual analysis of the College Anthem would be based on its verbal texts and context of usage. Okpala (2015:206) cited Nwamara (2006) that song texts communicate matters of interest. Songs texts are powerful tools in music. Although Nwobu (2019:107) argue that music song and song texts work together to give the listener a clearer picture of an entire composition, that both are inseparable. The fact remain that song text 
may be analyzed bearing in mind the context of its usage. Nwobu (2019:113) quoted Aluede (2014) that:

For effective interpretation of music, one should identify the history and background of the song, and equally examine the context within which the song was composed before being able to relate effectively to any object within which is encoded the meaning and knowledge of the culture which generates the corpus of such songs being interpreted.

Since a brief history and background of the College of Education, Agbor has previously been discussed (under the subheading: a brief perspective of the College of Education, Agbor) in order to understand the song and context within which the song was composed, the texts of the College Anthem shall be analyzed below:

\section{Lyrics of the College Anthem}

\section{Refrain:}
Alma mater
College of Education, Agbor
We hail and adore thee
College of Education, Agbor
Loyalty, hard Work is our Pledge
We shall fight to bring you fame

Verse 1 For the good of man, our motto is

Verse 2 Alma mater, so majesty

Sited on the hill of Alihame

We will all uphold thy name

Alma mater dear

What is an anthem? Chukwuka (2015:15) cited Randel (2000:28) that 'anthem' is a choral composition with a sacred or moralizing text in English, performed in a liturgical or ceremonial context. Oxford 
Advanced Learner's Dictionary defined 'anthem' as a song which has a special importance for a country or an organization and is sung on special occasions (p.40). The BBC English Dictionary explained 'anthem' as a song which is used to represent a particular nation, society or organized group and which is sung on special occasions. According to Wikipedia, anthem is a musical composition of celebration, usually used as a symbol for a distinct group. Dictionarycom define anthem as a song of praise, devotion, or patriotism for example the national anthem, college anthem while Vocabulary.com stated that an anthem is a rousing, reverential, sometimes even revolutionary song that represents the ideals of a group of people, YourDictionary.com defined an anthem as a piece of music intended to be sung to express patriotism, love, or commitment.

The above definitions express these thoughts, that an anthem is a song, a musical composition composed for a group of people, community, organisation or society that express the ideals and love, commitment, patriotism for that group sung on special occasion. These features are inherent in the College Anthem.

The College Anthem was composed by Elsie E. Nwoko in 1982 for the College of Education is hinged on the implicit and explicit function of the College as an institution of higher learning. The anthem is used for various occasions in the College such as induction programmes, matriculation, convocation and so forth. The College Anthem is a poem about College of Education, Agbor. Olaniyan (2008:150) describe a poem as the work of a creative writer in verse, visually emphasizing notable feeling or emotion or grandeur thought out in well painted language written and/or rendered with the aim of communicating an experience. Communication on the other hand, is the process of expressing ideas and feelings (Ineritei, 2006:618). When we communicate we exchange information, news, feelings or ideas. 
The word 'Alma mater' appeared three times on (line one of refrain, and line one and four of verse 2 respectively). According to BBC English dictionary alma mater is the college or school that one attended (p. 32). Oxford Advanced Learner's Dictionary alma mater is the school or university somebody went to (p. 30). MerriamWebster defined Alma mater as a school, college or university which one has attended or from which one has graduated. The Cambridge Dictionary defined alma mater as the school, college or university where you studied. While Vocabulary.com said that your alma mater is your old school, college or university. It is generally used as a positive term, implying reverence and loyalty for the nurturing qualities of the institution.

The above definitions captured vividly the whole texts of the College Anthem. The College Anthem preached about and/or advertised the nurturing qualities of the College. This is expressed in verse 1 line 1 of the College anthem thus 'For the Good of Man our motto is'. The text also described the Geographical (physical) and demographic location of the College site - this may be found in verse 2, line 1 and 2 'Alma mater so majesty; Sited on the hills of Alihame'. The text incites an image of a colossal and majestic field of production, sited on the hills of a community in Ika land known as 'Alihame'. The College hand book report that:

The College is located at Alihame in Agbor, Ika South Local Government Area. Alihame Community unreservedly donated the parcels of land siting the College. Having completed many building projects in the permanent site with many of them in use over the years, the seat of administration of the College finally moved to the permanent site only in 2008. (p. 1)

The essence and ideal of sustainable development in any country is to create structures and institutions that would create economic stability. College of Education, Agbor as an institution 
fulfilled the role of human capacity development because the text gave a vivid picture of a solid structure housing a gigantic academic enclave. In fulfilling the human capacity developmental goal and ensuring the development of the citizenry, the College run various courses in order to prepare the present generation of students for the sustainability of the entity called Nigeria thus one of the reason why the College of Education, Agbor was established in 1979 was to create sustainable development for Nigeria through the courses run in the College via the different departments and each year students are graduated. The anthem also eulogized College of Education, Agbor using personification 'We hail and adore thee' found on line 3 of the refrain to personify the college as a human entity.

Verse 1 lines 2 and 3 and Verse 2 line 2 run thus:

Loyalty, hard work is our pledge,

We shall fight to bring you fame

We will all uphold thy name

Ekong (2008:21) averred that patriotism and national spirit are often expressed in the lyrics (texts) of songs which have been conceived, created and performed. Here, patriotism is the key words and patriotism according to Adelugba (2004) cited by Ekong (2008:20) is love for one's county, devotion to its welfare and willingness to sacrifice for it. Adelugba further described a patriot as one who has the virtues, passions and actions which inspire him to serve his country. The sum total of this lexeme is service to one's country. Loyalty and service to one's nation implies that one is willing to accept responsibilities and take up leadership roles with little or no fear.

Hence, the outlined texts of the College anthem above signify a kind of patriotic spirit that should cloth graduates who had passed through the College their alma mater. By so doing, while serving the country and contributing meaningfully to the nation/society they the 
alma maters are torch bearers, an extension of College of Education, Agbor. The anthem also spoke of self-reliant (... hard work is our pledge) which is the end goal and an important aspect of human capacity and/or capital development.

\section{The College Anthem and its Implication for Sustainable Development}

Music contribute to the all-round development of the individual thus the music education programme is a comprehensive education system embodying the aesthetic, cognitive, affective, psychomotor domain aspects of learning geared towards a functional artistic career and career opportunities in the society and the development of the society. Ekong $(2008: 20,21)$ stated that music is a humanizing factor, playing a role in self-realization, self-identification, and self-development, touching man's whole body, his mind, his emotions and helping him to ease tension and boredom, giving him a sound mind in a sound body. With this, he would be able to contribute meaningfully to his immediate environment and the larger society, imbibing desirable national ideologies and value systems.

The whole idea-logy (that is, the whole logic) behind the ideals of sustainable development is to create a value system for the present generation without necessarily affecting the future of future generation - music and/or music education programme fulfils that role. This fact is supported by Idolor (2014:3) when he said that, in building a society, promoting solidarity, creating meaning, and imagining possibilities, music connects the individual to the society and the personal to the social. It is in this interconnectedness with human endeavours that music finds its societal usefulness and the need to comply with most current developments.

What is the most current development? The clarion call today is a call to sustainable development, development that can boost the economy of Nigeria in all ramification - education for all (not just 
education but quality education) is the answer to achieving sustainable development. Knowing that College of Education, Agbor has a unit (the Music Department), that music as a subject has the potential for enhancing the human personality; ensuring this human personality, self-realization, and self-development can only be achieved through complete involvement in inquiry and creative approaches to learning, it is important that this unit (music education programmed) is not ignored. The composer of the College Anthem Elsie E. Nwoko in penning this artistic creativity using the medium of sound (music) and texts (lyrics) is invariably advocating the importance of the music programme as a tool for sustainable development. The fact is that the country needs a sane society without a sane society many things will go hay-wire.

\section{Conclusion}

The message of a song is entrenched in the song texts and in analyzing a song text it is imperative to analyze such text(s) considering its historical perception and the background surrounding the text(s) including the content and/or context hence the paper analyzed the textual context/content of the College Anthem vis-a-vis the College of Education, Agbor and its implication for sustainable development in Nigeria. The College Anthem was geared towards elucidating the potentiality of the College of Education, Agbor as a facilitator of human capacity/capital development. The paper noted that Nigeria's development cannot be divorced from her educational institutions, since Nigeria's education system has many outlets the College of Education, Agbor is one of these outlets. There is therefore, a clarion call for investment in quality education which is apt to achieving sustainable development in Nigeria. If the goal of sustainable development is to meet the needs of today without compromising the needs of tomorrow, then Sustainable Development must be integrated into education and education must be integrated 
into sustainable development. The Nigeria Certificate in Education ( $\mathrm{N}$ C E ) is being threatened because of lack of employment opportunities to graduates who are being relegated to the background by the government of the day. This threat to the existence of Colleges of Education in Nigeria is costing to the institution resulting to lack of studentship in nearly all units of departments run by the College compared to her former glory where there is hardly a space for students to sit. Education must be strengthened in all agendas, programmes, and activities that promote sustainable development. In this vein, every sector and unit (departments) of the College of Education, Agbor must be invested on most especially the music education programme. Music/music education programme cut across all the domain of learning - the cognitive, affective, and psychomotor in addition to aesthetic - good quality music education programme should be encouraged, it is an essential vehicle and/or tool for achieving sustainable development. On a final note, without the College of Education, Agbor, there would be no College Anthem in Ika land composed principally for the College.

Justina Enoh Okafor, PhD

Department of Music

College of Education

Agbo

\section{References}

Aluede, C. O. (2014). Towards a theoretical foregrounding in Textual analysis of Esan Songs. Nigeria Music Review (13), Ile-Ife: Department of Music, Obafemi Awolowo University. 51-63.

Aninwene, E. O. (2006). Music Education: A Vehicle for Enhancing Ethnic Harmony in Nigeria. Awka Journal of Research in Music and the Arts (AJRMA), (3), 68-78. 
Okafor: Textual Analysis of College Anthem and Its Implication for Sustainable Development in Nigeria

Chukwuka, C. (2015). A Survey of Linguistic aspects of Church Music Composition in Igboland. Studies in Nigerian Music Book 1 (edited by Ogisi, A. A), 12-19.

Ekong, G. E. (2008). Re-creating Music for Self-Reliance and Patroitism. Awka Journal of Research in Music and the Arts (AJRMA), (5), 16-25.

Eya, L. O. (2000). "Achieving National Unity and Development through National Educational Psychology. SOSAN 3(1), 142156.

Hornby, S. (2001). Oxford Advanced Learner's Dictionary $\left(6^{\text {th }}\right.$ edition). Publisher: OUP Oxford.

Idolor, G. E. (2014). The Traditions of Okpe Disco and the Challenges of Modernism. $37^{\text {th }}$ Inaugural Lecture of the Delta State University, Abraka. Printed and Published by University Printing Press, Delta State University, Abraka

Ineritei, K. I. (2016). Images and Messages in Naija Hip-Hop Music Video: A Critical Analysis of Timaya's Plantain Boy and P. Square's E No Easy. Music Scholarship, Culture andPerformance Challenges in $21^{\text {st }}$ Century Africa: A Critical Resource Book in Honour of Emurobome Idolor (edited by Kenneth Efakponana Eni, Benedict Binebai and Solomon Oziakpono Ikibe), 617-627

John, S. \& Collins, C. (1992). BBC English Dictionary. Publisher: HapperCollins

Okafor, J. E., Abugu, T. P. \& Osborn, O. O. (2014). Elsie Ezinnwa Nwoko: An Art Music Composer and Music Education Practitioner. West African Journal of Musical Arts Education (WAJMAE),2(2), 145-157.

Okafor, J. E., Abugu, T. P. (2016). Women and Leadership Position in Nigeria: A case of College of Education, Agbor Delta State. Journal of National Association of Women in

Colleges of Education (JOWICE), 20(1), 129-132. 
Okpala, H.N. (2015:206). Song-texts-a tool for Global Reconciliation: A Study of Selected Igbo Songs. ANSU Journal of Arts and Humanities, 2(2), 199-204.

Olamiyan, O. (2008). The Manifestation of the Poetic Aptitude of the Yoruba Dundun Master Drummer within the Framework of Dundun Music. Awka Journal of Research in Music and the Arts (AJRMA), (5), 95-110.

Nwobu, S. N. (2019). Communication in Igbo Music: The Textual Analysis of Mike Ejeagha's 'Ife Uwa Bu Ana Emeodika Ada Eme'. Journal of the Association of Nigerian Musicologists (13), 106-117.

(2010/2011). Student Information Handbook College of Education, Agbor, Delta State (19 ${ }^{\text {th }}$ edition). Produced by THE STUDENT AFFAIRS DEPARTMENT PROVOST'S OFFICE COLLEGE OF EDUCATION, AGBOR. Printed and bounded in Nigeria by NICHO PRINTING WORKS.

Tetsola, E. A. (2005). The Birth of the College of Education, Agbor: The Dramatis, Personae, a 'Special Silver Jubilee'. A Lecture delivered by the Poineer Provost of the College of Education, Agbor, Chief Dr. Emmanuel Awatete Tetsola (JP) on Wednesday $14^{\text {th }}$ December, 2005, 1-10.

\section{Other Source(s)}

Allan McKee (2001). Textual Analysis: A Beginner's Guide. https://en.m.wikipedia.org>wiki Retrieved October $29^{\text {th }}$, 2019

Brundtland Report of 1987 http://en.m.wikipedia.org>wiki Retrieved October 30th, 2019

Elaine Nevin (2008). Education and Sustainable Development. www.wikipedia.com Retrieved October 30th, 2019

Microsoft ${ }^{\circledR}$ Encarta ${ }^{\circledR} 2009$

https://www.yourdictionary.com Retrieved October 26th, 2019 
Okafor: Textual Analysis of College Anthem and Its Implication for Sustainable Development in Nigeria

https://www.merriam-webster.com/dictionary/analysis

Retrieved

October 29th, 2019

https://en.m.wikipedia.org>wiki Retrieved October $29^{\text {th }}, 2019$

www.businessdictionary.com>analysisRetrieved October $29^{\text {th }}, 2019$

www.webster.com Retrieved October 26th, 2019

https://methods.sagepub.copm>sage Retrieved October 26th, 2019

http://en.m.wikipedia.org>wiki.

Retrieved October 26th, 2019

http://www.dictionary.com>browse Retrieved October 29th, 2019

https://www.vocubulary.com>anthem Retrieved October 26th, 2019

http://www.merriam-webster.com Retrieved October 30th, 2019

http://dictionary.cambridge.orgRetrieved October 29th, 2019

http://www.vocabulary.com>alma. Retrieved October 26th, 2019

\section{Appendix}
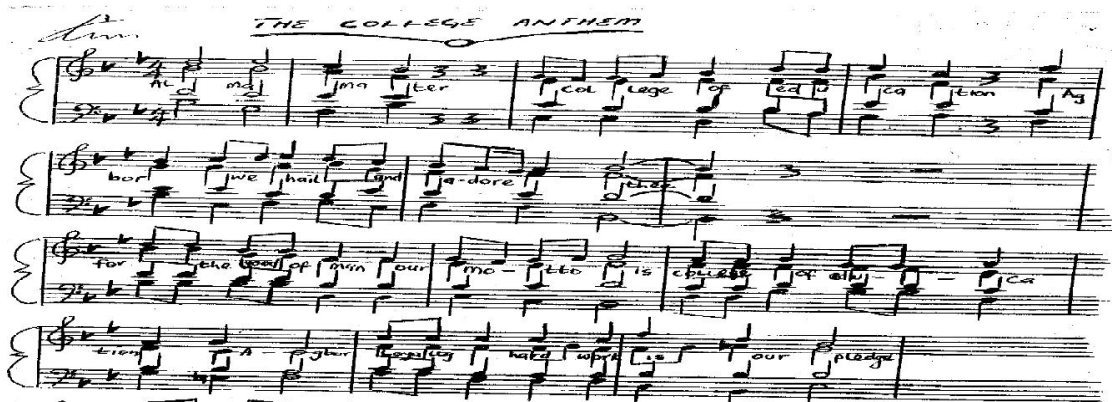

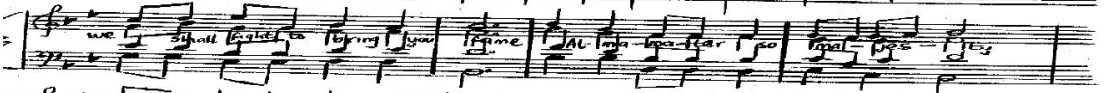
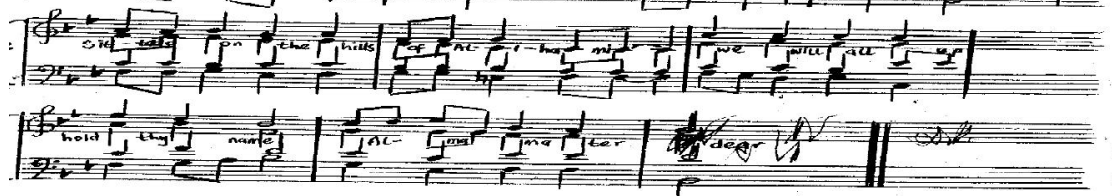